\title{
Kernos
}

Revue internationale et pluridisciplinaire de religion grecque antique

$20 \mid 2007$

Varia

\section{Ritual mutilation in Apollonius Rhodius' Argonautica}

A contextual analysis of IV, 477-479 in search of the motive of the $\mu \alpha \sigma \chi \alpha \lambda 1 \sigma \mu o ́ \varsigma$

\section{Reinhart Ceulemans}

\section{(2) OpenEdition}

Journals

\section{Electronic version}

URL: https://journals.openedition.org/kernos/173

DOI: $10.4000 /$ kernos. 173

ISSN: 2034-7871

\section{Publisher}

Centre international d'étude de la religion grecque antique

\section{Printed version}

Date of publication: 1 January 2007

Number of pages: 97-112

ISSN: 0776-3824

\section{Electronic reference}

Reinhart Ceulemans, "Ritual mutilation in Apollonius Rhodius' Argonautica", Kernos [Online], 20 | 2007, Online since 24 May 2011, connection on 08 September 2022. URL: http://journals.openedition.org/ kernos/173; DOI: https://doi.org/10.4000/kernos.173 


\title{
Ritual mutilation in Apollonius Rhodius' Argonautica. A contextual analysis of IV, 477-479 in search of the motive of the $\mu \alpha \sigma \chi \alpha \lambda \iota \sigma \mu \rho^{*}$
}

\begin{abstract}
In Apoll. Rh., Arg. IV, 477-479 Jason mutilates the corpse of Apsyrtus. To date, there has been a great deal of scholarly disagreement concerning the motive of this $\mu \alpha \sigma \chi \alpha \lambda \iota \sigma \mu$ ós: either the mutilation was intended as a cathartic appeasement sacrifice, or its goal was to avert the vengeance of the victim's ghost. This article opens up a new perspective by examining the ritual within the broader context of the fourth book of the epic. The appeasement motive is generally considered to have originated with Apollonius. However, a contextual study shows that he meant to apply the vengeance motive. All the signs that indicate an appeasement sacrifice can be explained in other ways. Moreover, Apollonius more than once explicitly refers to the defilement of Medea and Jason. The conclusion is that Jason mutilated Apsyrtus in order to avert his vengeance, not to bring an offering of atonement.

Résumé : Dans Apoll. Rh., Arg. IV, 477-479, Jason mutile le corps d'Apsyrtos. Jusqu’à présent, le motif de ce $\mu \alpha \sigma \chi \alpha \lambda \iota \sigma \mu o ́ s$ a fait débat: ou bien la mutilation est vue comme une offrande expiatoire et cathartique, ou bien l'on considère que son objectif était d'éviter la vengeance de l'esprit de la victime. Cet article ouvre une nouvelle perspective en examinant le rite dans le contexte plus large de l'épopée d'Apollonios, qui semble être le point de départ du motif expiatoire. Néanmoins, une lecture contextuelle montre qu'il a plutôt tendu à appliquer le motif de la vengeance. Tous les signes indiquant un sacrifice expiatoire peuvent être expliqués d'une autre façon. En outre, Apollonios se réfère plusieurs fois explicitement à la souillure de Jason et Médée. Dès lors, il s'avère que Jason a mutilé Apsyrtos pour éviter sa vengeance et non pour offrir un sacrifice expiatoire.
\end{abstract}

In the fourth book of Apollonius' Argonautica, a striking passage has been the cause of great debate. After his description of how Jason snuck up behind the unsuspecting Apsyrtus and killed him, the Rhodian writes these gruesome verses:

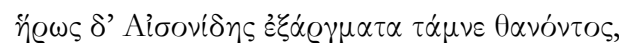

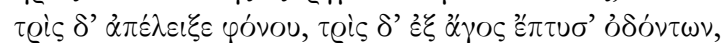

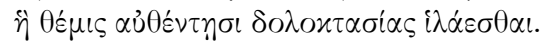

${ }^{*}$ My thanks are due to Prof. Dr. Peter Van Deun (Leuven) and Dr. Vinciane PirenneDelforge (Liège), who both commented on previous drafts of this article. 
the hero, son of Aison, cut off the dead man's extremities; three times he licked the blood, and three times he spat the pollution out from his teeth, as is the proper way for slayers to expiate treacherous murders (IV, 477-479)1.

In verse 477, a specific form of mutilation is described, viz. the $\mu \alpha \sigma \chi \alpha$ $\lambda \iota \sigma \mu o ́ s$, the precise meaning of which is difficult to grasp ${ }^{2}$. Apollonius' adaptation of the ritual occupies a central role in this debate ${ }^{3}$, but until now this passage has not been examined in the broader context of (the fourth book of) the Argonautica. This article conducts this inquiry, as such an examination is the best way to clarify the matter, especially the difficult questions concerning reason and motive.

\section{Apollonius and Aristophanes: opposite views}

Apollonius compresses the actions of cutting off the extremities and licking and spitting out the blood (pollution) into less than three verses. The only explanation he offers is in verse 479: it seems to be an act of expiation. To the modern reader the action seems very cruel and barbarous, but this was certainly also an obscure rite for Apollonius. In the Hellenistic era there was already

\footnotetext{
${ }^{1}$ English translations of the Argonautica are always quoted from that of R.L. HUNTER (1993). Quotations of the Greek text are taken from the edition in three volumes by F. VIAN (19741981). For every other translation there is a reference to the source; where there is none, it concerns a personal translation.

${ }^{2}$ Contributions concerning the $\mu \alpha \sigma \chi \alpha \lambda \iota \sigma \mu o$ s are often old and/or concise. Among them, the most elaborate are: G.L. KITTREDGE, "Arm-pitting among the Greeks," AJPh 6 (1885), p. 151169; A. Gotsmich, "Der Maschalismos und seine Wiedergabe in der griechischen Kunst," in H. NotTARP et al. (eds.), Monumentum Bambergense. Festgabe fuir Benediket Kraft, Munich, 1955 (Bamberger Abhandlungen und Forschungen, 3), p. 349-366; M. TEUFEL, Brauch und Ritus bei Apollonios Rhodios, Diss. Doct., Tübingen, 1939, p. 102-110; E. RoHDE, Psyche. The Cult of Souls and Belief in Immortality among the Greeks (Transl. W.B. Hillis), London/New York, 1925 [Heidelberg, 1920], p. 582-586. Other useful literature includes: S.I. JohnsTON, Restless Dead: Encounters between the Living and the Dead in Ancient Greece, Berkeley et al., 1999, p. 156-159; E. Vermeule, Aspects of Death in Early Greek. Art and Poetry, Berkeley et al., 1979 (Sather Classical Lectures, 46), p. 236 n. 30; M.P. Nilsson, Geschichte der griechischen Religion, Munich, 19673 [1940] (Handbuch der Altertumswissenschaft, 5.2), I, p. 99-100; M. MARCOVICH, "Bedeutung der Motive des Volksglaubens für die Textinterpretation," QUCC 8 (1969), p. 31-34; R. PARKER, "A Note on yóvos, Ovoía and


Mnemosyne 26 (1973), p. 62-63. In order to gain a view on the prevailing theories concerning the different aspects of the $\mu \alpha \sigma \chi \alpha \lambda \iota \sigma \mu$ s$_{\text {s, }}$ one should consult these works (and their bibliography), e.g. that of Kittredge. This article presents itself as exploring the meaning of the ritual in the Argonautica, especially in discovering its motive and rationale. For further bibliography and a status quaestionis concerning the different theories on the latter point, cf. n. 31-35.

${ }^{3}$ At this point one should consider Apollonius' extensive interest in magical rituals, as it is aired elsewhere in his epic, pace HUNTER, o.c. (n. 1), p. xxvi: "The diminution of the full Olympian 'apparatus' is compensated for by an interest in the human confrontation with the strange and the magical." Although Apsyrtus' mutilation is an essential part of the story tradition of the Argonauts, nowhere else this act is placed in the broader scope of a religious rite. It is the merit of Apollonius that he managed to expand this traditional element with a new perspective, viz. that of a magic ritual.
} 
discussion concerning the precise meaning of the ritual. The treatment by Apollonius has played a crucial role in this discussion, but this verse and the surrounding passage are anything but easy to interpret. By his extreme concision the poet evokes a mysterious and grim atmosphere, which leaves the reader with a "clouded, imperfect knowledge of motive, purpose, and even fact"4.

The scholion on Apollonius' Argonautica 5 explains that "the killers in former days used to perform certain mutilations on the murdered corpse, viz. by cutting off its outermost parts; hereafter they hung these parts around the neck [...]. After they subsequently took from his blood, they thrice spat it out. This they usually did with a view to atone for their deceitful murder". The scholiast confirms that it is an expiation ritual, but does this by deducting a great deal of his text directly from the source text, so this scholion should be read with caution.

A different view is proposed by Aristophanes Byzantinus. He says that "those who have murdered someone by treachery cut off his extreme parts, in order to avert his wrath, strung them together and hung them from their neck, pulling them through the armpits; these parts they called $\mu \alpha \sigma \chi \alpha \lambda i \sigma \mu \alpha \tau \alpha "$. Whereas Apollonius and his scholiast speak of an appeasement ritual, Aristophanes mentions a motive of averting the revenge of the murdered

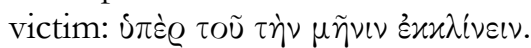

Two different motives are suggested to explain the $\mu \alpha \sigma \chi \alpha \lambda \iota \sigma \mu o ́ \varsigma$ ritual, both of which were later elaborated upon by ancient scholiasts and lexicographers? p. 4.

${ }^{4}$ C.S. Byre, “The killing of Apsyrtus in Apollonius Rhodius' Argonautica," Phoenix 50 (1996),

${ }^{5}$ Schol. Apoll. Rh., Arg. IV, 477-479 (ed. Wendel [1974], p. 286-287).

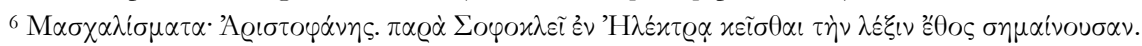

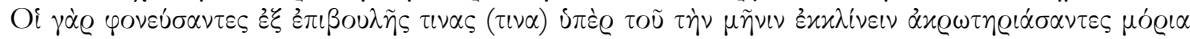

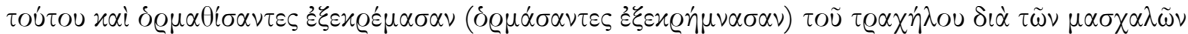

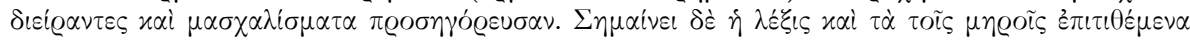

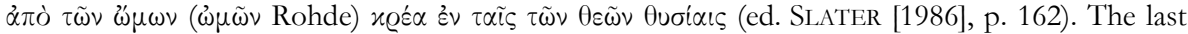

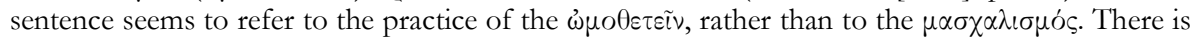
one inscription (SEG 35,113), which provides the only attestation of the term $\mu \alpha \sigma \chi \alpha \lambda i \sigma \mu \alpha \tau \alpha$ in its secondary sense. Cf. E. VANDERPool, "A Lex Sacra of the Attic Deme Phrearrhioi," Hesperia 39 (1970), p. 47-53 (p. 49) and especially E. LuPU, "M $\alpha \sigma \chi \alpha \lambda i \sigma \mu \alpha \tau \alpha:$ A Note on SEG XXXV 113," in D. Jordan \& J. Traill (eds.), Lettered Attica. A Day of Attic Epigraphy. Proceedings of the Athens Symposium, 8 March 2000, Toronto, 2003 (Publications of the Canadian Archaeological Institute at Athens, 3), p. 69-77 and id., Greek Sacred Law. A Collection of New Documents (NGSL), Leiden/Boston (RGWR, 152), 2005, p. 166-168, the latter author offering a thorough analysis of the inscription and reflecting on the mutual aspects of the $\dot{\omega} \mu \circ \theta \varepsilon \tau \varepsilon i \nu$ and the $\mu \alpha \sigma \chi \alpha \lambda i \zeta \varepsilon i \nu$.

7 Averting the vengeance: Aristophanes; scholia Choephori and Electra; Pausanias, Hesychius, Photius and Suda, s.v. $\mu \alpha \sigma \chi \alpha \lambda i \sigma \mu \alpha \tau \alpha$; Etymologicum Magnum, s.v. $\mu \alpha \sigma \chi \alpha \lambda i \zeta \varepsilon \iota v$. Appeasing the murder: Argonautica and scholion; Pausanias, Suda, Ps.-Zonaras and Lexicon Sabbaiticum, s.v. $\varepsilon \mu \alpha \sigma \chi \alpha \lambda i \sigma \theta \eta$ and (only Suda) $\mu \alpha \sigma \chi \alpha \lambda \iota \sigma \theta \tilde{\eta} \nu \alpha \iota$; Etymologicum Genuinum, s.v. $\alpha \pi \alpha \dot{\varrho} \gamma \mu \alpha \tau \alpha$; Michael

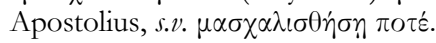


One group says that catharsis or atonement is the goal of the mutilation while the other sees it as the corpse being disfigured so that the revenge of its ghost would be averted.

\section{Classical 'praxis' vs. Byzantine 'scholarship': problems in interpretation}

In classical literature the verb $\mu \alpha \sigma \chi \alpha \lambda i \zeta \varepsilon \iota \nu$ appears twice, viz. in Aeschylus' Choephor 8 and in Sophocles' Electra ${ }^{9}$. A scholion to the Choephori ${ }^{10}$ explains that the whole defiling act including the $\mu \alpha \sigma \chi \alpha \lambda i \zeta \varepsilon \iota \nu$ was performed by Clytemnestra

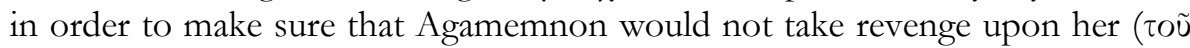

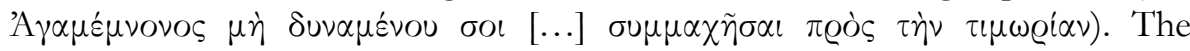
scholion on the Electra ${ }^{11}$ consists of two glosses which seem to give different motives for the mutilation, but in fact amount to the same $e^{12}$. The $\alpha$-gloss says that the murderer, by disfiguring the corpse, takes away the power of the dead, and thus avoids the latter's revenge. The $\beta$-gloss speaks of catharsis, but then clarifies that the goal is to make the corpse weak, so that it cannot take revenge


scholiasts, in both classical passages the $\mu \alpha \sigma \chi \alpha \lambda$ เ $\mu_{\text {ó }}$ s must be interpreted as a ritual to avoid vengeance.

All three instances of $\mu \alpha \sigma \chi \alpha \lambda$ ı $\sigma$ ó in Greek literature (Aeschylus, Sophocles and Apollonius) are extremely brief. M $\alpha \sigma \chi \alpha \lambda \iota \sigma \mu o ́ s$, for example, is an expression that is used only by the lexicographers ${ }^{13}$. Only the related verb $\mu \alpha \sigma \chi \alpha \lambda i \zeta \varepsilon i \nu$ occurs in the classical authors. Apollonius does not even use either of these words.

The concision of both classical references to the $\mu \alpha \sigma \chi \alpha \lambda \iota \sigma \mu$ ó illustrates that the Athenian public at that time still knew perfectly well what kind of mutilation was intended. Thus, in the $5^{\text {th }}$ century BCE the expression $\mu \alpha \sigma \chi \alpha \lambda i \zeta \varepsilon \iota \nu$ and its significance must have been clear ${ }^{14}$. To the postclassical and Byzantine scholars however, the authors of the lexica and the scholia, the $\mu \alpha \sigma \chi \alpha \lambda$ i $\sigma$ ó

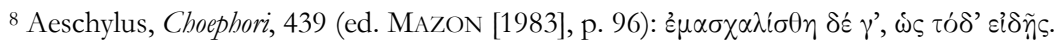

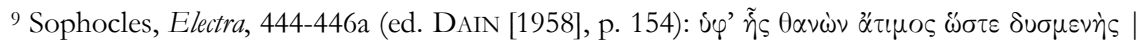

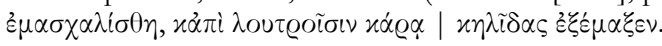

${ }^{10}$ Schol. Aesch., Choeph., 440-442 (ed. Sмiтh [1976], p. 26).

11 Schol. Soph., El., 445 (ed. Papageorgius [1888], p. 123-124).

12 On the nature of the glosses, cf. KiTTREDGE, l.c. (n. 2), p. 153.

13 Besides its lexicographic occurrences, the term $\mu \alpha \sigma \chi \alpha \lambda i \sigma \mu \alpha \tau \alpha$ only occurs in two other instances, viz. Soph., Troilus, fr. 623 (ed. RADT IV [1985], p. 455 - a fragment passed down only from the lexicons) and SEG 35, 113 (cf. supra n. 6).

${ }^{14}$ Cf. Gotsmich, l.c. (n. 2), p. 351 and RoHDE, o.c. (n. 2), p. 582.
} 
was no longer a clear subject ${ }^{15}$. Concerning this deep abyss which separates study from practice, Margarete Teufel even feels obliged to note: "falls sie [der $\mu \alpha \sigma \chi \alpha \lambda \iota \sigma \mu o ́ s]$ wirklich geübt wurde und nicht eine Erfindung der Grammatiker ist, herausgesponnen aus dem Worte $\mu \alpha \sigma \chi \alpha \lambda i \zeta \varepsilon \iota \nu^{\prime \prime 16}$. Exaggerated as this remark may be, it has some truth to it. To the authors of all these glosses and scholia the $\mu \alpha \sigma \chi \alpha \lambda \iota \sigma \mu$ ó $_{\text {is }}$ a ritual that is far away from them, a fossil from the ancient past ${ }^{17}$. It is exactly because of this reason that an Alexandrine scholar such as Apollonius, a couple of centuries after the classical era, sneaked the ritual into his erudite epic. Many centuries later still, the lexicographers tried to explain it. In the course of this process, older views were passed on, and one scholarly study of the ritual generated another like it. It is no surprise that interpretation errors emerged from this chain of explanations. In this particular case, Apollonius played a decisive role.

The starting point of the scholarly interest is Aristophanes Byzantinus. Academic opinion is divided on the source of his explanation. William Slater, for example, notices that at least a part of Aristophanes' theory could have been an $\alpha \dot{0} \tau 0 \sigma \chi \varepsilon \delta i \alpha \sigma \mu \alpha$, an improvisation ${ }^{18}$. Erwin Rohde ${ }^{19}$, however, has great faith in what Aristophanes said on the matter, and resolutely rejects this possibility. According to Rohde, one has to stay close to Aristophanes' outlook, which he has not developed on the basis of his own speculation but through another channel, viz. with "actual knowledge". If the latter is correct, Aristophanes' explanation can be considered as the basis for the post-Apollonian research ${ }^{20}$,

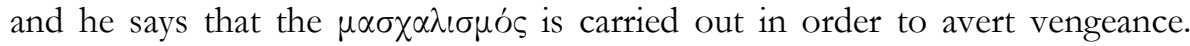
However, this is hardly reconcilable with the fact that Apollonius ${ }^{21}$ seems to state that it was a ritual to atone.

Present-day scholars deal with the same problems as did the lexicographers a few centuries ago, as they still do not exactly know what the $\mu \alpha \sigma \chi \alpha \lambda \iota \sigma \mu o ́ s$ was. A multitude of questions are still awaiting definitive answers, one of the most important ones being that of the precise motive. Why, with what goal, did

\footnotetext{
15 Cf. the statement of GotSmich, l.c. (n. 2), p. 352: "nach dem 5. Jhdt. entschwand die eigentliche Bedeutung des Wortes $\mu \alpha \sigma \chi \alpha \lambda i \zeta \varepsilon \iota \nu$ der Kenntnis des Volkes, so da $\beta$ zum Verständnis Erklärungen nötig waren."

16 TEUfEL, o.c. (n. 2), p. 105

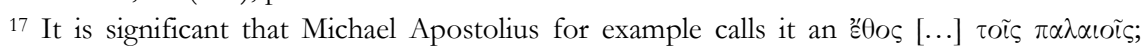

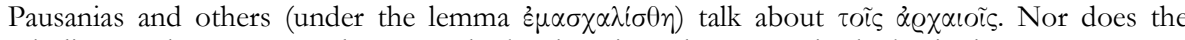
scholion on the Argonautica leave any doubt: there it reads $\alpha \varrho \alpha \alpha i \omega \varsigma$ in the beginning.

18 SLATER, o.c. (n. 6), p. 162.

${ }^{19}$ ROHDE, o.c. (n. 2), p. 583.

20 Cf. A.F. Garvie, Aeschylus, Choephori, with introduction and commentary, Oxford, 1987 [1986], p. 163: "[...] Aristophanes of Byzantium, who may be the ultimate source of all the ancient notices".

${ }^{21}$ All the lexicons etc. that support the appeasement motive can be traced back to Apollonius. The Rhodian thus is the only original source and starting point of this theory.
} 


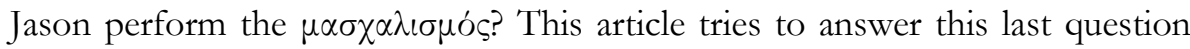
and begins by identifying three plausible motives.

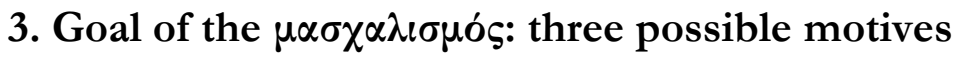

The first possible explanation is that by hanging the extremities around the corpse, the killer tries to evoke the impression that the victim himself has done harm to his own person. He then mutilates the deceased in order to deprive him of the possibility of revenge. At the basis of this ritual lies the Greeks' fundamental belief that a dead person arrives in the underworld in exactly the same condition as on the moment of his death ${ }^{22}$. The primitive idea that the person comes back in his full corporality also seems to play a part. According to this view, when one mutilates the body the deceased will be unable to retaliate. In that way, the mutilation is a security measure against the "living corpse' that returns to haunt and punish the murderer ${ }^{23}$. The mutilation of the body is assumed to effect a corresponding mutilation of the wuxy so that the ghost, deprived of his extremities, would be powerless to take vengeance on the murderer. (For the sake of convenience, from now on this motive will be referred to as the 'vengeance motive'.)

The second explanation is, according to some, under discussion in the passage from the Argonautica. The description of the $\mu \alpha \sigma \chi \alpha \lambda i \sigma \mu \alpha \tau \alpha$ as $\varepsilon \xi \dot{\alpha} \varrho \gamma \mu \alpha \tau \alpha$ is of crucial importance. This word, a hapax created by Apollonius, seems to denote the same as the terms $\ddot{\alpha} \varrho \gamma \mu \alpha \tau \alpha$ or $\dot{\alpha} \pi \dot{\alpha} \varrho \gamma \mu \alpha \tau \alpha$, meaning the $\dot{\alpha} \pi \alpha \varrho \chi \alpha i$, the firstlings of the sacrificial animal that is offered to the gods. More specifically, this seems to mean that the $\mu \alpha \sigma \chi \alpha \lambda i \sigma \mu \alpha \tau \alpha$ are the firstlings of the murdered victim. This term, in combination with the presence of the verb $i \lambda \dot{\alpha} \varepsilon \sigma \theta \alpha$, has led various scholars ${ }^{24}$ to (wrongly - of. infra) conclude that the whole act is meant to sacrifice the murdered person as some sort of averting sacrifice or $\dot{\alpha} \pi \circ \tau \varrho \sigma i \alpha \sigma \mu \alpha$. Without any doubt, these scholars are inspired by the explanations presented by the scholion on the Argonautica and other ancient sources ( $c f$. supra n. 7). As they stated, the $\mu \alpha \sigma \chi \alpha \lambda \iota \sigma \mu$ ó would then be a sacrifice intended to avert evil, or a cathartic sacrifice, which practically amounts to the same idea. The prevailing idea is that while one appeases the gods, one passes the defilement onto the victim himself. (This motive is referred to from now on as the 'appeasement motive'.)

A third possible reason for the $\mu \alpha \sigma \chi \alpha \lambda \iota \sigma \mu$ ó is easier to find: the more ordinary desire to humiliate the victim post mortem and make him look like a fool ${ }^{25}$. This motive is not explicitly mentioned in any of the lexicons or scholia,

${ }^{22}$ Cf. e.g. Hom., Odyssey XI, 40-41 and Aesch., Eumenides, 103.

${ }^{23}$ Cf. Teufel, o.c. (n. 2), p. 108.

${ }^{24}$ E.g. Rohde, o.c. (n. 2), p. 584-585 and KitTredge, l.c. (n. 2), p. 154. Cf. also n. 32 and 34.

25 Vermeule, l.c. (n. 2), p. 236 n. 30. 
but it is reasonable to assume that it was often present in the background. One can assume that in the references of Sophocles and Aeschylus to the death of Agamemnon the motive of humiliation plays along 26 : the mutilation of the Mycenaean king was exactly the opposite of actual funerary rites. It is very probable that this motive also was latently present in the writing of Apollonius. By mutilating Apsyrtus, Jason deprives him of his $x \alpha \lambda o ̀ \varsigma ~ \theta \alpha ́ v \alpha \tau o \varsigma^{27}$ because "in losing its formal unity, the human body is reduced to the condition of a thing

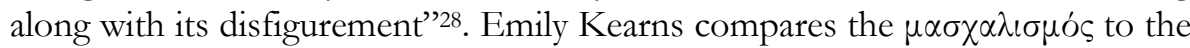
cruel, humiliating treatment of the goatherd Melanthius in the Odyssey (XXII, 474-477) ${ }^{29}$.

It appears that the third motive could be combined with one of the first two, which seem incompatible with each other. Either Jason is motivated by vengeance or by appeasement, but not both. The final objectives of both motives are rather similar, as in both cases it is the intention of the murderer to escape the consequences of the crime. But according to one motive he wants to escape the revenge of his victim, and according to the other the defilement, the

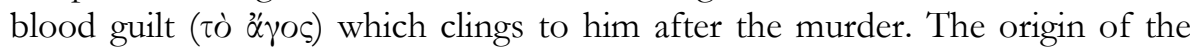
vengeance theory is Aristophanes, while Apollonius initiated the appeasement theory.

There is no consensus in modern scholarly research on the question which of these two motives ${ }^{30}$ is actually intended in this passage (IV, 477-479). A large number of scholars who reflect on the Argonautica or on aspects of Greek religion related to those of the $\mu \alpha \sigma \chi \alpha \lambda$ i $\mu$ ós do not mention the strange mutilation at all. Other authors in the same area briefly mention the $\mu \alpha \sigma \chi \alpha \lambda i \zeta \varepsilon \iota \nu$, but do not comment or reflect on the motive that is actually involved ${ }^{31}$. Another group leaves the question open, but carefully suggests either the appeasement motive $^{32}$ or the vengeance motive ${ }^{33}$. Still other scholars do not hesitate to

\footnotetext{
26 E. KEARnS, s.v. “maschalismos,” Oxford Classical Dictionary (1996), p. 934.

27 JOHNSTON, o.c. (n. 2), p. 151. p. 71.

28 J.-P. Vernant, Mortals and immortals: collected essays (ed. F.I. Zeituin), Princeton, 1991,

${ }^{29}$ KEARNS, l.c. (n. 26), p. 934.

${ }^{30}$ In this brief status quaestionis I only looked at the appeasement and the vengeance motive. The motive of the humiliation is given no consideration.

31 Teufel, o.c. (n. 2), p. 105-110; Marcovich, l.c. (n. 2), p. 32; Parker, l.c. (n. 2), p. 138; P. DrÄGER, Die Argonautika des Apollonios Rhodios. Das zweite Zorn-Epos der griechischen Literatur, Leipzig, 2001, p. 41; KEARNS, l.c. (n. 26), p. 934; HunTER, o.c. (n. 1), 156-157; the Argonautica edition of E. LIVREA (1973), p. 153

32 Kittredge, l.c. (n. 2), p. 157; P. STENGEL, Die griechischen Kultusaltertïmer, Munich, $1920^{3}$ (Handbuch der klassischen Altertumswissenschaft, 5.3), p. 160; R.C. JEBB, Sophocles, The Plays and Fragments, Part VI: The Electra, with critical notes, commentary, and translation in English prose, Amsterdam, 1962 [Oxford, 1924], p. 66, 211-212.

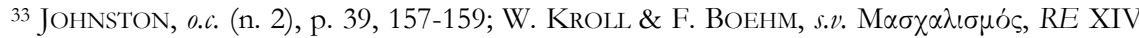
(1930), col. 2060-2062; F. RüsCHE, Blut, Leben und Seele. Ihr Verbältnis nach Auffassung der griechischen
} 
answer the question and support either the appeasement ${ }^{34}$ or the vengeance motive $^{35}$. Thus, while both of the motives have lived on in scholarly explanations, a univocal decisive answer has yet to be provided.

\section{M $\alpha \sigma \chi \alpha \lambda \iota \sigma \mu o ́ \varsigma$ in light of the Argonautica}

Until now, this passage (IV, 477-479) has never been examined in the broader context of (the fourth book of) the Argonautica. However, a contextual analysis can shed light on the question of motive. As stated above, Apollonius has been regarded as the catalyst for the appeasement motive, as his description of the $\mu \alpha \sigma \chi \alpha \lambda$ ı $\mu$ ó $\varsigma$ brought scholars to think of it as an atonement ritual. However, when one considers the context, there are hardly any arguments for such a motive. The few elements that may be indicative turn out to be very doubtful indeed. This makes it uncertain whether Apollonius really intended to present the $\mu \alpha \sigma \chi \alpha \lambda$ i $\mu$ ó as $_{\text {an }}$ appeasement ritual. In fact, there are but two elements that seem to favour the appeasement motive. First there is verse 479 in which, by way of $i \lambda \alpha^{\varepsilon} \varepsilon \sigma \theta \alpha^{36}$, there is an explicit reference to an atonement. Second there is the word $\varepsilon^{\xi} \dot{\alpha} \varrho \gamma \mu \alpha \tau \alpha$, which can be seen as indicating a sacrificial context. However, when one studies the passage in its broader context, it soon appears that there are other reasons for these two elements.

\subsection{Two elements of appeasement?}

\subsection{1. $i \lambda \dot{\alpha} \varepsilon \sigma \theta \alpha \imath$}

The reader notices at once that the $\mu \alpha \sigma \chi \alpha \lambda$ เ $\mu$ ós is mentioned in one breath

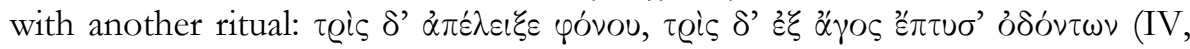
478). Jason thrice licks up the blood of Apsyrtus, and thrice he spits it out. Spitting counted as a cathartic, apotropaic gesture: when the murderer spits out

und hellenistischen Antike, der Bibel und der alten Alexandrinischen Theologen. Eine Vorarbeit zur Religionsgeschichte des Opfers, Paderborn, 1930 (Studien zur Geschicbte und Kultur des Altertums, 5), p. 101-102; S. EiTREM, Opferritus und Voropfer der Griechen und Römer, Hildesheim/New York, 1977 [Kristiana, 1915], p. 417 (indirectly); GARVIE, o.c. (n. 20), p. 163.

34 RoHDE, o.c. (n. 2), p. 584-585 (and Vernant, o.c. [n. 28], p. 71 n. 37); VermeUle, o.c. (n. 2), p. 236; W. KAssies, De tocht van de Argonauten. Jason, Medea en het Gulden Vlies, Amsterdam, 2000 [1996], p. 349; VIAN, o.c. (n. 1), p. 167; LSJ (1996), s.v. $\mu \alpha \sigma \chi \alpha \lambda i \sigma \mu \alpha \tau \alpha$; E. RIESS, "Volksthümliches bei Artemidoros," RhM 49 (1894), p. 177-193 (p. 182-183).

35 Gotsmich, l.c. (n. 2), p. 363; J.N. BREMmER, "Why did Medea kill her brother Apsyrtus?," in J.J. Clauss \& S.I. Johnston (eds.), Medea: essays on Medea in myth, literature, philosophy and art, Princeton, 1997, p. 83-100 (p. 84); R. GARLAND, The Greek Way of Death, London, $2001^{2}$ [1985], p. 94; Nilsson, o.c. (n. 2), p. 99; H. Lloyd-Jones, The Justice of Zeus, Berkeley et al., 1973 [1971] (Sather Classical Lectures, 41), p. 75; P. CHANTRAINE, Dictionnaire étymologique de la langue grecque. Histoire des mots, Paris, 1968, II, p. 671; LSJ (1996), s.v. $\mu \alpha \sigma \chi \alpha \lambda i \zeta \omega$; DAIN, o.c. (n. 9), p. 154; G. KAIBEL, Sophokles, Electra, Sammlung wissenschaftlicher Commentare, Stuttgart, 1967 [1896], p. 141; MAZON, o.c. (n. 8), p. 96-97.

36 The word $i \lambda \dot{\alpha} \varepsilon \sigma \theta \alpha l$ is an epic variant for i $\lambda \dot{\alpha} \sigma \varkappa \varepsilon \sigma \theta \alpha l$, and means 'to appease' ( $c$. LSJ [1996], s.v.). 
the blood, he averts the $\alpha$ oros, the blood guilt ${ }^{37}$. The underlying idea is that the murderer transfers the stain to the murdered person: "Spitting is an obvious and almost instinctive rite of purification"38. It cannot be denied that verse 479 (with the $i \lambda \dot{\alpha} \varepsilon \sigma \theta \alpha$ ) directly follows the spitting ritual and not the suggested

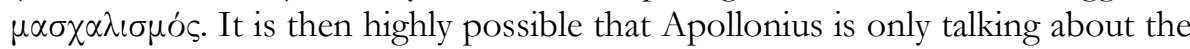

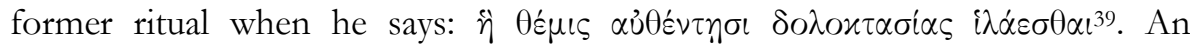
analogous situation occurs in the scholion on this passage, which merely reformulates the passage of Apollonius. The last line of that scholion runs:

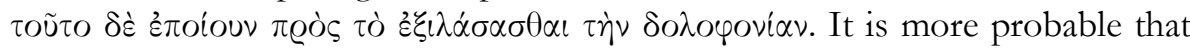

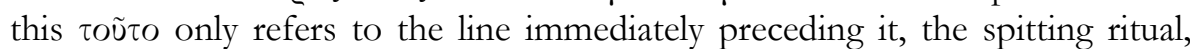
rather than to what is said in the beginning of the scholion. If the scholiast had meant that the mutilation too (which he discussed in the beginning of the scholion) was an appeasement ritual, then a $\tau \alpha \tilde{\nu} \tau \alpha$ rather than a $\tau$ $0 \tilde{\tau} \tau O$ would have been more appropriate.

Apollonius' own comment is thus deactivated as an argument for appeasement ${ }^{40}$. This is a negative argument: it does not prove that the mentioned $\mu \alpha \sigma \chi \alpha \lambda i \zeta \varepsilon \iota \nu$ per se is not an appeasement ritual, but it does allow for serious doubt to be put to Apollonius' presumed reference to that motive.

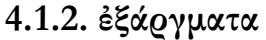

According to a number of scholars (cf. supra n. 7, 32 and 34) the word ¿̇ $\dot{\alpha} \varrho \gamma \mu \alpha \tau \alpha$ seems to point to an atonement, a cathartic offering. This term, a creation of Apollonius', is coined out of other literary concerns and does not evoke the appeasement context as some readers argue. Of course, one may consider why several readers have thought of this context, due to the connection with the following verse 478. As mentioned before, the spitting actually evokes an appeasement ritual. This may offer an explanation as to why the word $\dot{\varepsilon} \xi \dot{\alpha} \varrho \gamma \mu \alpha \tau \alpha$ was interpreted in that manner. By mentioning $\pi \tau \dot{v} \varepsilon \iota \nu$, an atmosphere of appeasement was created, an atmosphere in which the magical

${ }^{37}$ Cf. Hunter, o.c. (n. 1), p. 157, Bremmer, l.c. (n. 35), p. 84 and Teufel, o.c. (n. 2), p. 112; the latter author contends that the spitting also thwarts the revenge of the dead person. To the present argument this is hardly relevant.

38 Kittredge, l.c. (n. 2), p. 157.

39 BYRE, l.c. (n. 4), p. 14 n. 35 , considers this verse to be an ironic or cynical comment of Apollonius. This interpretation would fit the current argumentation, but since Byre neglects to motivate or substantiate his view, it will be left aside.

${ }^{40}$ In opposition to this thesis one could observe that the $i \lambda \dot{\alpha} \varepsilon \sigma \theta \alpha \iota$ actually does denote an

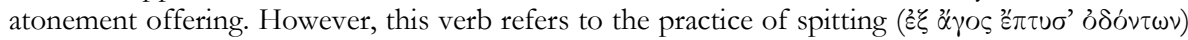

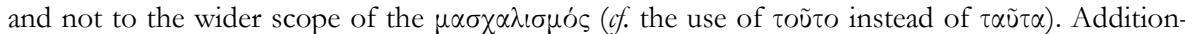
ally, the $\pi \tau \dot{v} \varepsilon \iota \nu$ in $478 \mathrm{~b}$ is balanced by the $\alpha \pi 0 \lambda \varepsilon i x \varepsilon \iota \nu$ in $478 \mathrm{a}$. Jason licks up the blood and spits it out, thus line 478 forms a complete whole, with the two opposite acts balancing each other. The act of deceiving, murdering and mutilating doesn't find its counterpart in the brief description of the spitting. This is a more extensive part, and in order to be in balance, it must have an extensive counterpart, which is in the scene in which Jason and Medea are cleansed by Circe ( $c f$. infra). 
ritual of the $\mu \alpha \sigma \chi \alpha \lambda$ เouós could also be set. This might be the reasoning of those who reason an appeasement motive from the term $\varepsilon^{\xi} \xi \dot{\alpha} \varrho \gamma \mu \alpha \tau \alpha$.

As outlined before, the word $\xi^{\xi} \xi \dot{\alpha} \gamma \mu \alpha \tau \alpha$ does not denote an appeasement, but merely a sacrificial context. The term is a synonym of $\dot{\alpha} \pi \dot{\alpha} \varrho \gamma \mu \alpha \tau \alpha$ and thus of $\alpha \pi \alpha \varrho \chi \alpha$ ', and means 'firstlings' or 'sacrifice'. This perspective has nothing to do with the $\pi \tau v^{\prime} \varepsilon \nu$ or atonement. One may wonder why Apollonius wrote this specific word $\xi^{\xi} \dot{\alpha} \varrho \gamma \mu \alpha \tau \alpha$ and intended a sacrificial aspect in this passage. When the reader looks back only a few lines, he runs into several words which all denote a sacral context. The term is evoked by the sacral atmosphere pervading the wider context of the passage, and the specific implication of 'sacrifice' seems to be less significant than the general religious connotations of the word.

\subsection{Murder and sacrifice}

One must keep in mind what precedes this passage: Medea and Jason have murdered Medea's stepbrother Apsyrtus. In IV, 464-467 Jason jumps out from his ambush with the bare sword in his hand. From there the passage continues: "As the slaughterer at a sacrifice kills a great, horned bull, so did Jason strike down his prey [...]. In the vestibule of the temple he [Apsyrtus] sank to his knees, and $[\ldots]$ his life ebbed away" (IV, 468-472a). The translation 'slaughterer' is unfortunate and vague; in Greek it reads ßovтú but a common word. This term, when compared to the more frequent

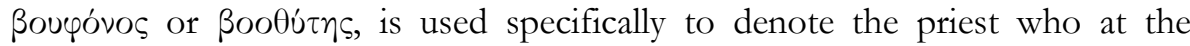
Bouphonia was responsible for the killing of the ox in front of the altar of Zeus Polieus ${ }^{41}$. These Bouphonia were the most important event during the feast of

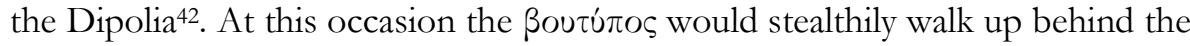
ox which was about to be sacrificed and kill it with one mighty blow ${ }^{43}$. The parallel to Jason and Apsyrtus speaks for itself, for the poet himself explicitly states that "the son of Aison leapt from his cunning ambush, the naked swordblade raised in his hand" (IV, 464-465a).

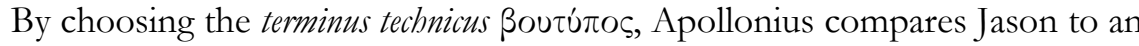
official sacrificial priest. In this way he places the murder in a sacrificial context. It is no coincidence that the scene takes place in sacred territory, viz. the pronaos of Artemis' temple (IV, 469-470), as it resembles the Bouphonia,

41 J.R. PORTER, "Tiptoeing through the Corpses: Euripides' Electra, Apollonius, and the Bouphonia," GRBS 31 (1990), p. 266. Cf. LSJ (1996), s.v. ßoutútoc: "ox-butcher, slanghterer [...]; esp.

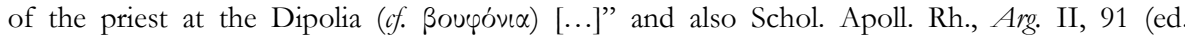

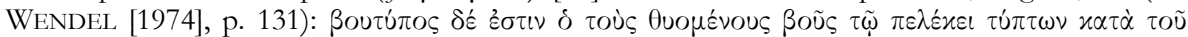

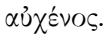

42 Cf. F.P. Walton, s.v. "Dipolieia," Lexicon der alten Welt (1965), col. 762 and P. STENGEL, Opferbräuche der Griechen, Leipzig/Berlin, 1910, p. 203-221.

43 PORTER, l.c. (n. 40), p. 276. 
which take place at the altar of Zeus Polieus ${ }^{44}$. Moreover, murder in poetry is often looked upon as a perverted sacrifice ${ }^{45}$ and the Bouphonia seem to form a bridge between the twin phenomena of murder and sacrifice. "The term Bouphonia means 'murder [ழóvos] of the ox [ßoũs]' and hence from the outset already calls into question the division between murder and sacrifice" 46 .

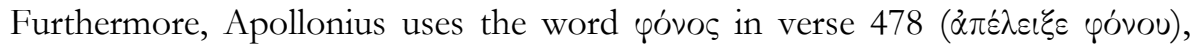
directly after the description of the $\mu \alpha \sigma \chi \alpha \lambda \iota \sigma \mu o ́ s$. Thus it is made clear that it is hard to discriminate between murder and sacrifice in this entire passage.

In that way, the murder of Apsyrtus is already steeped in the atmosphere of a sacrificial rite prior to the $\mu \alpha \sigma \chi \alpha \lambda \iota \sigma \mu o ́ s$ passage. This knowledge can offer an explanation for the choice of the word $\xi \xi \alpha \varrho \mu \alpha \tau \alpha$ : it is all but likely that the evoked sacrificial atmosphere still lasted nine verses later and tempted Apollonius to choose a term which fits in this context. Specifically, this means that the significance of 'sacrifice' and 'firstlings' can be explained as echoes of the preceding context. In verse 477 then, the term $\xi^{\xi} \xi \alpha \operatorname{\alpha } \gamma \mu \alpha \tau \alpha$ is coined out of literary concerns, and is not used in the literal sense of referring to a sacrifice.

It thus may be proved that in the narrower scope of the passage 477-479, the $\mu \alpha \sigma \chi \alpha \lambda \iota \sigma \mu o ́$ is not necessarily presented as an appeasement ritual, since the two factors which support this, the words $i \lambda \dot{\alpha} \varepsilon \sigma \theta \alpha l$ and $\varepsilon \xi \dot{\alpha} \varrho \gamma \mu \alpha \tau \alpha$, can be justified otherwise. The appeasement perspective, which some scholars read into the term $\dot{\xi} \xi \dot{\alpha} \varrho \gamma \mu \alpha \tau \alpha$, actually relies on nothing but the $\pi \tau \dot{v} \varepsilon \iota \nu$ ritual, and is even unexpected in the scope of Greek sacrificial ritual ${ }^{47}$. Within the broader framework of the fourth book, there are still more elements that plead against the appeasement motive and in favour of the vengeance motive.

\subsection{In favour of the vengeance motive}

One obvious argument pleads for the application of the vengeance motive. One must keep in mind why Medea and Jason killed Apsyrtus in the first place, viz. so that the Argonauts could escape from their pursuers. The latter had cornered the Argo sailors, and "the Minyans would have succumbed in grievous war, a small force overcome by a larger one" (IV, 338-339a). That is why Jason gets the idea to murder their leader Apsyrtus, because, as he reasons, "the local peoples will not be so hostile to us in their desire to please the Colchians, when the leader [...] is not there" (IV, 405b-406; cf. also IV, 499b$502)$.

\footnotetext{
44 PorTer, l.c. (n. 40), p. 264, 266. The cleansing of Jason's sword by Circe (IV, 696-687a) would then correspond to the purification of the axe at the Bouphonia, cf. R. PARKER, Miasma. Pollution and Purification in early Greek Religion, Oxford, 1983, p. 117 n. 55.

45 PARKer, l.c. (n. 2), p. 138.

46 Vernant, o.c. (n. 28), p. 298.

${ }^{47} \mathrm{I}$ am indebted to Dr. Vinciane Pirenne-Delforge for her help in developing several points in the foregoing argumentation.
} 
It is entirely in the interest of the Argonauts that the situation remains as it is: if the ghost of the murdered Apsyrtus would take revenge and reassemble the Colchians in one way or other, the Greeks would have no chance. Thus, it is logical that Jason would have performed the $\mu \alpha \sigma \chi \alpha \lambda \iota \sigma \mu o ́ s$ in order to hold off the revenge of Apsyrtus' ghost. If the victim could still come to take vengeance, there would have been no purpose to the murder.

\subsection{Against the appeasement motive}

In addition, various factors plead against the application of the appeasement motive. Each of the three following observations confirms the same crucial point, that Jason is unclean after verses 477-479 and he and Medea are not purified. This is totally at odds with the appeasement motive. Briefly, Jason still needs to be purified, he gives evidence of the qualities of a defiled person

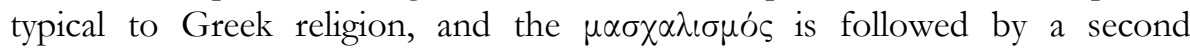
defilement.

\subsubsection{Postponed purification}

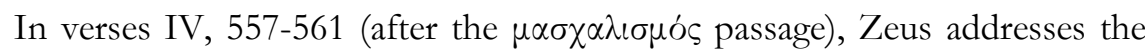
Argonauts: "When the tall body of Apsyrtos crashed to the ground in death, Zeus himself, the king of the gods, was no doubt seized by anger at what they had done. He devised that they [the Argonauts] should be cleansed of the blood of the murder by the skill of Aiaian Kirke, and return home after enduring numberless sufferings. None of the heroes knew this $[\ldots]$ ". Shortly after this passage the fearful Argonauts are advised by the talking mast of the Argo: "[the voice] said that they could not escape from their suffering on the vast ocean and the terrible storms until Kirke had cleansed them from the pitiless murder of Apsyrtos" (IV, 585b-588a). It is emphasized twice that Jason cum suis still need to be cleansed, and the blood guilt still stains them. Thus it is clear that Jason and Medea are as yet impure after the mutilation.

These two passages are not just gap fillers by Apollonius. He clearly points this out by actively describing the cleansing by Circe a few lines later. Apollonius pays a great deal of attention to the purification of Jason and Medea, in one of the most remarkable scenes of the epic. He devotes nearly one hundred verses to the episode, which contains many magical elements (IV, 659-752). It is worth mentioning that a purification ritual like the one described in this passage does not appear anywhere in the Homeric epics. One gets the impression that Homer actually avoids the rendering of such primitive, bloody religious customs ${ }^{48}$, while Apollonius the scholar seizes the occasion to include such a rare episode. It would be strange if he would cut the ground from under his own feet by referring shortly and very obscurely to the theme of the magical

\footnotetext{
${ }^{48}$ Cf. KAssies, o.c. (n. 34), p. 353.
} 


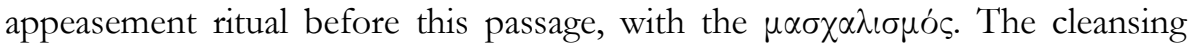
itself does not need to be dwelt on, it is sufficient for this argument to know that it occurs. Precisely by its extensive and explicit presence in the text, the purification episode proves that no similar event has occurred before.

In the episode with Circe, Apollonius leaves no doubt that Jason and Medea indeed are unclean. His choice of words makes the defiled status of Jason and

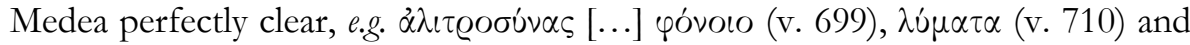

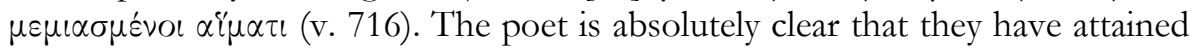
this defiled status through the guileful murder of Medea's own brother ( $c$.

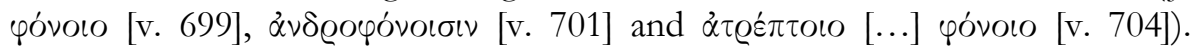
Therefore, Circe will make an appeal to Zeus, the god of purification

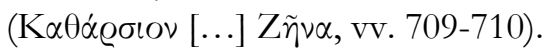

Thus, it is beyond question that the actual cleansing of Jason and Medea takes place here, and nowhere else. Apollonius says this very clearly in verse 702: $\dot{\alpha} \pi \circ \lambda u \mu \alpha i v o v \tau \alpha \iota^{49}$. One must also keep the warnings of Zeus and the Argo's mast in mind, who both said explicitly that the murderers needed to be purified by Circe. This purification is obviously stressed by the words $\alpha$ rovı $\psi \alpha \mu \varepsilon \dot{v}$ ous (v. 560) and víqeıv (v. 588). These commands are fulfilled in the Circe episode, meaning that Jason could not have atoned for the murder directly afterwards with the $\mu \alpha \sigma \chi \alpha \lambda i \zeta \varepsilon v$. The fact that purification happens with Circe by means of

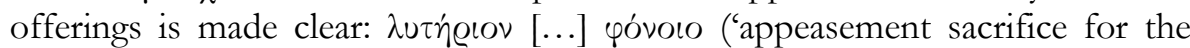
murder', v. 704) and $\mu$ si $\lambda$ ex $\varrho \alpha$ ('propitiation offerings', v. 712).

Shortly after the $\mu \alpha \sigma \chi \alpha \lambda \iota \sigma \mu o$ s passage, the reader is notified twice by a divine speaker of the defiled status of Jason and Medea. Purification seems necessary, and comes in the passage with Circe, together with an appeasement sacrifice. It seems clear that such a thorough cleansing and reconciliation would be illogical if Jason had already atoned for the murder by disfiguring Apsyrtus.

\subsubsection{Protagonists in the background}

It is also striking that, between the death of Apsyrtus and the purification by Circe, Jason and Medea hardly appear in the story. Once they have rejoined the Argo sailors after the murder, it is mentioned only briefly that Medea joins the deliberating men (IV, 493b-494a). Her name is not even mentioned, she is but a xoúgn. From then on, she is consequently ignored until she steps into the

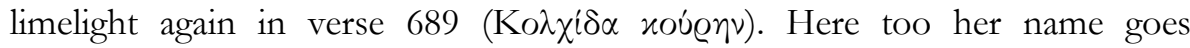
unmentioned and is not spoken again until verse 815, after the purification with Circe.

Jason too, although leader of the Argonauts, is strikingly absent. After the murder of Apsyrtus it is not him, but Peleus who immediately makes the decisions (IV, 494b). It is also Peleus who sets out the further plans (IV, 495-

${ }^{49}$ Cf. LSJ (1996), s.v. $\alpha \pi \circ \lambda u \mu \alpha i v o \mu \alpha l:$ "cleanse oneself by bathing, esp. from an $\ddot{\alpha} \gamma o \varsigma$ [...]." 
503), and generally the 'young men' who agree (véoı, IV, 503). Jason disappears anonymously into the group. The only time he appears again is where the past is concerned in IV, 527-536. Even there he is not referred to nominatim, as only his patronymic Aioovion is mentioned (IV, 530). Then, after Peleus' sudden assumption of leadership, actions are taken among others by Polydeuces and Castor (IV, 588-596), but remarkably never by Jason, the actual captain of the expedition. The first action which Jason himself performs is planting his sword in the ground in Circe's house as a sign that it needs to be purified.

Nonetheless, there are enough occasions for Apollonius to involve Medea

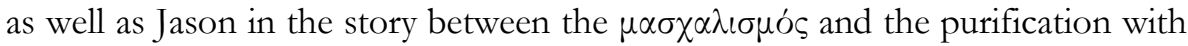
Circe. For example, when he shortly introduces the sorceress Circe (IV, 590b591), he could have said that she is Medea's aunt, as in Hellenism both magicians were closely associated with one another ${ }^{50}$. Likewise, when Apollonius renders the regulations of Zeus and the mast of the Argo, that Jason and Medea need to be cleansed, it would have been normal and obvious to mention them at that point. Yet, he deliberately leaves them out of the narrative. This silence is so striking that it seems practically impossible that the poet would use it without a good reason. The blatant absence of Jason and Medea could well be an indication of the fact that they are still defiled.

Robert Parker, who has examined defilement and purification in Greek religion, leaves no doubt about the status of the stained person: "That the blood of his victim clings to the hand of a murderer, and, until cleansed, demands his seclusion from society, is a belief attested in a bewildering variety of literary, oratorical, historical, mythographical, and pictorial sources"51. The $\mu i \alpha \sigma \mu \alpha$, the $\alpha \gamma o \varsigma$, which clings to the murderer, is contagious. Applying this view to this passage, it immediately becomes clear why Apollonius puts Jason and Medea, both responsible for Apsyrtus' death, aside: the stain of the murder still sticks to them, and so they are both taboo. As long as the blood guilt clings to them, they may not actively participate or even speak ${ }^{52}$. After the purification with Circe, Jason and Medea regain their active roles, suggesting that the atonement of the murder does not occur with the mutilation. Again the appeasement motive does not hold.

50 For example, some Hellenistic beliefs make Circe and Medea sisters, with the magic goddess Hecate as their mother ( $c f$. H. PARRY, Thelxis: Magic and Imagination in Greek Myth and Poetry, Lanham et al., 1992, p. 49).

51 PARker, o.c. (n. 43), p. 104. Cf. Teufel, o.c. (n. 2), p. 119: “[der Mörder] ist tabu, d.h. er wird von der übrigen Gesellschaft ausgeschlossen, isoliert, um seine Mitmenschen nicht anzustecken."

52 Cf. TEufEL, o.c. (n. 2), p. 120: “über den ungereinigten Mörder [ist] das Redeverbot verhängt." 


\subsubsection{Double ä́os}

Supposing that Jason would disfigure Apsyrtus in order to cleanse himself and rid himself of the stain, it would be strange if immediately after that ritual another contamination would follow. Nevertheless, this is what happens, as IV,

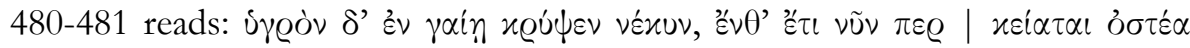

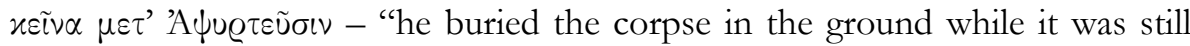
fresh; to this day those bones lie among the Apsyrteis". This description must be compared to Apollonius' very explicit comment on the funeral rituals of the Colchians, that it is not proper for them to bury the dead in the earth ( $c f$. III, 202-209).

For Apsyrtus to be buried according to the customs of his people, he should have been hung from a tree. Jason, however, is portrayed putting the Colchian captain under the ground without further ado (for the corpse is still humid, íyeóv!), "unter Nichtbeachtung der kolchischen Luft-/ Baum-/ Fellbestattung" 53 . According to Colchian belief such a funeral is a serious guilt: $\alpha^{\prime} \gamma o \varsigma$

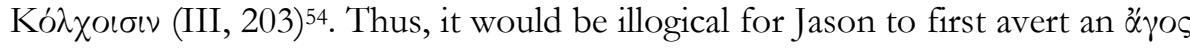
only to create a new one immediately afterwards.

Therefore, this burial adds to the evidence against the appeasement motive, but the reader can ask why Jason buries the corpse. After all, he could just leave the body be. It is highly plausible that Jason wanted to humiliate Apsyrtus post mortem by this burial, especially since in combination with a burial against Colchian customs, the $\mu \alpha \sigma \chi \alpha \lambda i \sigma \mu$ ó forms "an absolute inversion of proper

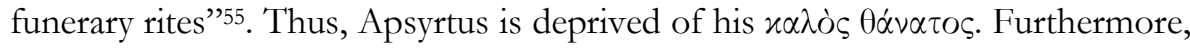
it seems that a psychological motive is also in play here which supports the vengeance motive. Instinctively, Jason wants to get rid of his victim as soon as possible. In some sort of magical reflex ${ }^{56}$, the murderer wants to remove the corpse of his enemy and to get it out of his sight. In the words of Sarah Johnston, "The swiftness of burial reflects not only the obvious need to remove a decomposing corpse quickly but the perception that the individual no longer belonged amongst the living" 57 . Jason wants to remove Apsyrtus from the surroundings and send him quickly to the underworld, to feel more secure. By executing this form of burial, Jason gains additional protection from the

\footnotetext{
${ }^{53}$ DRÄGER, o.c. (n. 31), p. 41.

54 One cannot suggest that Jason was unaware of this form of burial. For it is him who walked across the Plain of Circe, where the bodies of the Colchian men were hanging in the trees (III, 198b-200)! Jason knowingly does not comply to these Colchian practices, and buries Apsyrtus in a shameful manner.

${ }^{55}$ JOHNSTON, o.c. (n. 2), p. 158.

${ }^{56}$ In accordance with that notion of magic that says that by performing a very concrete act, one tries to affect the course of things; pace James Frazer's definition of 'sympathetic magic': $c f$. J.G. Frazer, The Golden Bough. A Study in Magic and Religion, Hertfordshire, 1993 [London, 1922], p. 11-48 (p. 12) and E. CSAPO, Theories of Mythology, Malden et al., 2005, p. $36-43$ (p. 38-40).

${ }^{57}$ JOHNSTON, o.c. (n. 2), p. 40.
} 
revenge of the deceased. So the double äyo not only weakens the appeasement motive, but also supports the vengeance motive.

\section{Conclusion}

A contextual study of IV, 477-479 has supported the interpretation that Jason killed Apsyrtus in a cunning way, and prior to burying him against the custom of his people, he cut the corpse into pieces, not to atone for the murder but to avoid the victim's revenge. Through their striking absence in the ensuing narrative, Jason and Medea are presented as still being defiled. It is only after the purification with Circe that they become clean again and return to participate in the actions, and only then is the murder truly appeased.

It seems clear that Apollonius does not intend to suggest the appeasement motive. The presence of the two words which may contradict this conclusion, $i \lambda \dot{\alpha} \varepsilon \sigma \theta \alpha \iota$ and $\varepsilon_{\xi}^{\prime} \alpha \varrho \gamma \mu \alpha \tau \alpha$, may be explained otherwise in light of the context. Therefore, Jason cuts Apsyrtus' corpse into pieces not in order to make an atonement sacrifice, but to escape the latter's revenge. Moreover, the motive of humiliation still has a part to play, as Apsyrtus is clearly denied a $2 \alpha \lambda \grave{o} \varsigma$ $\theta \dot{\alpha} v \alpha \tau o \varsigma$.

Until now, Apollonius has been traditionally considered the starting point of the appeasement motive. All secondary sources which argue for this motive derived from the Hellenistic poet. However, in the Argonautica passage a motive of averting revenge is in fact more likely, and it appears that the lexicographers, glossators and scholiasts interpreted Apollonius incorrectly ${ }^{58}$. Therefore, it seems that this one short passage from the Argonautica was responsible for the development of a sidetrack in ancient and modern reflections on the phenome-

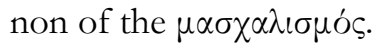

Reinhart CEULEMANS

Katholieke Universiteit Leuven

Faculty of Theology

Sint-Michielsstraat, 6

BE - 3000 LEUVEN

E-mail: reinhart.ceulemans@theo.kuleuven.be

58 Of course the possibility always exists that they had a different source in mind - after all, so much literature has disappeared. But this seems rather improbable, as in none of those writings another author or writing is actually mentioned. 